\title{
INFLUENCE OF THE BURDEN BY VARIOUS LEVELS OF PROFESSIONAL STRESS ON SERUM LIPIDS CONCENTRATION IN SECURITY OFFICERS
}

\author{
UDC 159.944:612.397:351.75
}

\author{
Jovica Jovanović ${ }^{1,2}$, Ivana $\breve{S a r a c}^{3}$, Jovana Jovanović ${ }^{1}$, \\ Dušan Sokolović ${ }^{1}$, Stefan Jovanović ${ }^{1}$ \\ ${ }^{1}$ Faculty of Medicine in Niš, University of Niš, Niš, Serbia \\ ${ }^{2}$ Institute of Occupational Health Niš, Niš, Serbia \\ ${ }^{3}$ Institute for Medical Research, University of Belgrade, \\ Center of Research Excellence in Nutrition and Metabolism, Belgrade, Serbia
}

\begin{abstract}
The aim of this work is to analyze the relationship between the level of professional stress and the concentration of total cholesterol, HDL cholesterol, LDL cholesterol and triglycerides in the serum of security employees. . The study included 415 security officers (exposed group) divided into four sub-groups and 150 administrative workers (control group). By applying a standardized questionnaire, the level of professional stress in their workplaces was calculated. To determine the serum lipid concentration in the all subjects, venous blood samples were taken in the morning after a twelve-hour food abstinence Security officers are exposed to a high level of professional stress, where the level of stress index depends on the type of the job they are engaged in. The highest values of the total index of professional stress, total cholesterol, LDL cholesterol and triglycerides were registered with the employees who transport money and those carrying firearms. The lowest total index of professional stress, total cholesterol, LDL cholesterol and triglycerides were registered with property security officers and persons who do not carry firearms. The correlation between the level of stress index at work, an increase in total cholesterol, LDL cholesterol, triglycerides and HDL cholesterol levels is statistically significant. We believe that there is a significant correlation between the level of the overall stress index at work and the risk of atherosclerosis in security officers.
\end{abstract}

Key words: security service, professional stress, cholesterol, triglycerides, $L D L$ cholesterol.

Received May 13, 2018 / Accepted November 9, 2018

Corresponding author: Jovica Jovanović

Faculty of Medicine, Department for Occupational Health Medicine, Zoran Đinđić Bčvd. 81, 18000 Niš, Serbia

E-mail: drjovicajovanovic@yahoo.com 


\section{INTRODUCTION}

In the labour market, everywhere in the world and in our country, in the past several decades, there has been a rise in demand for security officers [38], and there has been an increase in the number of agencies involved in security of assets and persons who have a significant role in reducing crime $[1,22,45]$. Security officers work in shifts and during the night, they are exposed to numerous professional risks, violence, physical attacks, conflicts, they own and use firearms, and their personal security is often at risk [10,28]. The jobs are usually performed at the premises of other employers or users of their services, which in particular affect their safety. Risks at their workplaces, and especially the stress to which they are exposed, attract special attention of the researchers.

\section{AIM}

The purpose of this research is to examine the link between the level of professional stress and the concentration of total cholesterol, HDL cholesterol, LDL cholesterol and triglycerides in the serum of officers engaged in different types of security.

\section{Methodology}

The survey covered a total of 415 security officers (examined group) divided into four subgroups, including 102 employees for the security of property and persons without carrying firearms (Subgroup1), 108 employees of security personnel for carrying firearms (Subgroup 2), 101 property security officers and persons carrying firearms (Subgroup 3) and 104 employees for providing transport of money carrying firearms (Subgroup 4). The control group consisted of 150 administrative workers. Using the standardized and authorized questionnaire, with the already obtained author approval, Dr. Karen Belkić [4] analyzed the level of professional stress in their workplaces. Of all subjects, a sample of venous blood was taken in the morning after a 12-hour abstinence from food. Total cholesterol and triglycerides were determined by standard enzymatic methods. HDL cholesterol was determined by the same method used for total cholesterol after precipitation of non-HDL lipoprotein. The concentration of LDL cholesterol was determined by Friedewald's formula [46]. Statistical methods were analyzed and the parameters between the examined and the control group, as well as between the individual subgroups within the investigated group, were compared. The correlation between the intensity of stress and lipid status parameters was also analyzed.

\section{RESULTS}

A statistically significant difference between these groups $(p<0.001)$ was observed between the mean values of the OSI index between the investigated $(85.44 \pm 3.94)$ and the control group $(48.10 \pm 2.23)$. The analysis of the OSI index in the tested subgroups of the investigated group showed that the highest values were among the employees providing the transport of money and carrying firearms $(88.66 \pm 7.34)$, which is statistically significantly higher than the control group ( $\mathrm{p}<0.001)$. Significantly higher values in relation to the 
control group were also held by security officers and persons carrying firearms $(87.47 \pm$ $3.49)$ ( $\mathrm{p}<0.001)$, security officers of carrying objects with firearms $(84.95 \pm 8,99)(\mathrm{p}$ $<0.001)$ and officers in securing property and persons without carrying firearms $(80.66 \pm$ 3.89) $(\mathrm{p}<0.001)($ Table 1).

Table 1 Comparative analysis of the OSI index in the examinees of the control, investigated groups and in the subgroups of the investigated group.

\begin{tabular}{lccccc}
\hline & $\mathrm{N}$ & $\overline{\mathrm{x}}$ & $\mathrm{SD}$ & Min & Max \\
\hline Control group & 150 & 48.10 & 2.23 & 33 & 57 \\
Examined group & 415 & 85.44 & 3.94 & 54 & 97,5 \\
Subgroup 1 of examined group & 102 & 80.66 & 3.89 & 54 & 89,5 \\
Subgroup 2 of examined group & 108 & 84.95 & 8.99 & 55 & 91,5 \\
Subgroup 3 of examined group & 101 & 87.47 & 3.49 & 70 & 97,5 \\
Subgroup 4 of examined group & 104 & 88.66 & 7.34 & 72 & 80.5 \\
\hline
\end{tabular}

By analyzing the middle values of the lipid status parameters, statistically significantly higher middle values of total cholesterol, LDL cholesterol and triglyceride values and statistically significantly lower value of HDL cholesterol levels were observed in the group of examinees compared to control group workers (Table 2).

Table 2 The average values of lipids in the examined and control group

\begin{tabular}{|c|c|c|c|}
\hline \multirow{2}{*}{$\begin{array}{l}\text { Parameter } \\
(\mathrm{mmol} / \mathrm{l})\end{array}$} & Examined group & Control group & $\mathrm{p}$ \\
\hline & $\mathrm{X} \pm \mathrm{SD}$ & $\mathrm{X} \pm \mathrm{SD}$ & $\mathrm{p}<0.001$ \\
\hline Total cholesterol & $6.33 \pm 1.14$ & $3.52 \pm 0.85$ & $\mathrm{p}<0.001$ \\
\hline HDL cholesterol & $1.04 \pm 0.59$ & $1.83 \pm 0.66$ & $\mathrm{p}<0.001$ \\
\hline LDL cholesterol & $4.29 \pm 1.32$ & $2.31 \pm 0.71$ & $\mathrm{p}<0.001$ \\
\hline Triglycerides & $3.27 \pm 1.21$ & $1.52 \pm 0.59$ & $\mathrm{p}<0.001$ \\
\hline
\end{tabular}

The highest values of total cholesterol, LDL cholesterol and triglycerides were registered with the employees in the provision of transport of money by carrying firearms, and the lowest value of these parameters for security officers and persons without wearing firearms. The lowest values of HDL cholesterol are registered with the employees providing transportation of money by carrying firearms, and the highest value of these parameters in the personnel for security of property and persons who do not carry firearms (Table 3).

Table 3 The average values of lipids in the test sub-groups of workers group.

\begin{tabular}{lccccc}
\hline $\begin{array}{l}\text { Parameter } \\
(\mathrm{mmol} / \mathrm{l})\end{array}$ & Subgroup 1 & Subgroup 2 & Subgroup 3 & Subgroup 4 & Control group \\
\cline { 2 - 6 } & $\mathrm{X} \pm \mathrm{SD}$ & $\mathrm{X} \pm \mathrm{SD}$ & $\mathrm{X} \pm \mathrm{SD}$ & $\mathrm{X} \pm \mathrm{SD}$ & $\mathrm{X} \pm \mathrm{SD}$ \\
\hline Total cholesterol & $4.82 \pm 1.39$ & $5.78 \pm 1.38$ & $6.44 \pm 0.99$ & $8.26 \pm 2.25$ & $3.52 \pm 0.85$ \\
HDL cholesterol & $1.37 \pm 0.56$ & $1,05 \pm 0.49$ & $0.92 \pm 0.42$ & $0.82 \pm 0.33$ & $1.83 \pm 0.66$ \\
LDL cholesterol & $3,35 \pm 0.56$ & $3.87 \pm 0.77$ & $4.45 \pm 1.22$ & $5.50 \pm 1.89$ & $2.31 \pm 0.71$ \\
Triglycerides & $2.17 \pm 1.09$ & $3.18 \pm 0.90$ & $3.46 \pm 1.27$ & $4.25 \pm 1.62$ & $1.52 \pm 0.59$ \\
\hline
\end{tabular}

In the examined group, a statistically significant positive correlation was observed between the total OSI index and total cholesterol. The total level of professional stress 
index over 75 leads to a significant increase in the total cholesterol level in the examined group (Graphic 1).

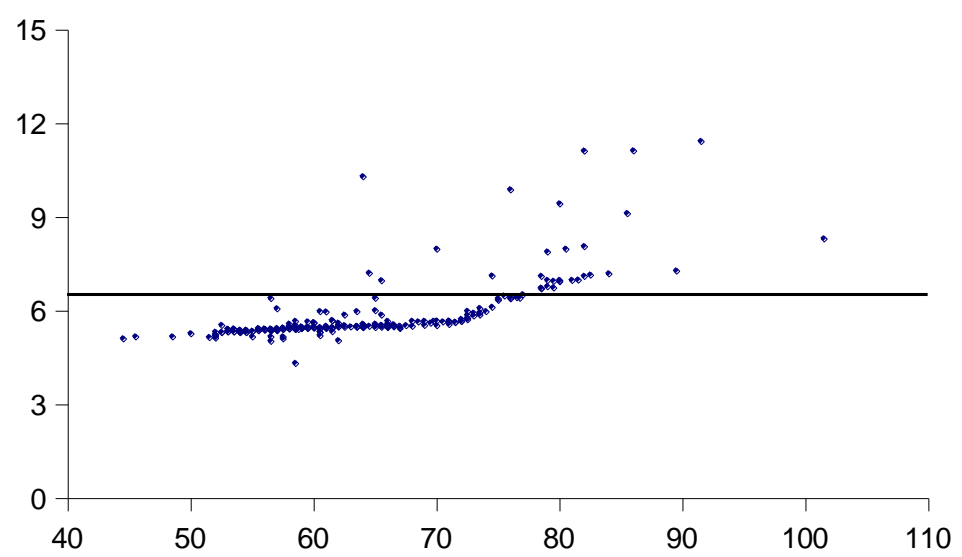

Fig. 1 Correlation analysis of total OSI total score ( $\mathrm{X}$ axis) and total cholesterol (mmol/l on Y axis) in the examined group

In the examined group, a statistically significant negative correlation was observed between the OSI index and the HDL cholesterol concentration. The level of professional stress index of 60 and higher results in decrease in the HDL cholesterol concentration in the examined group.

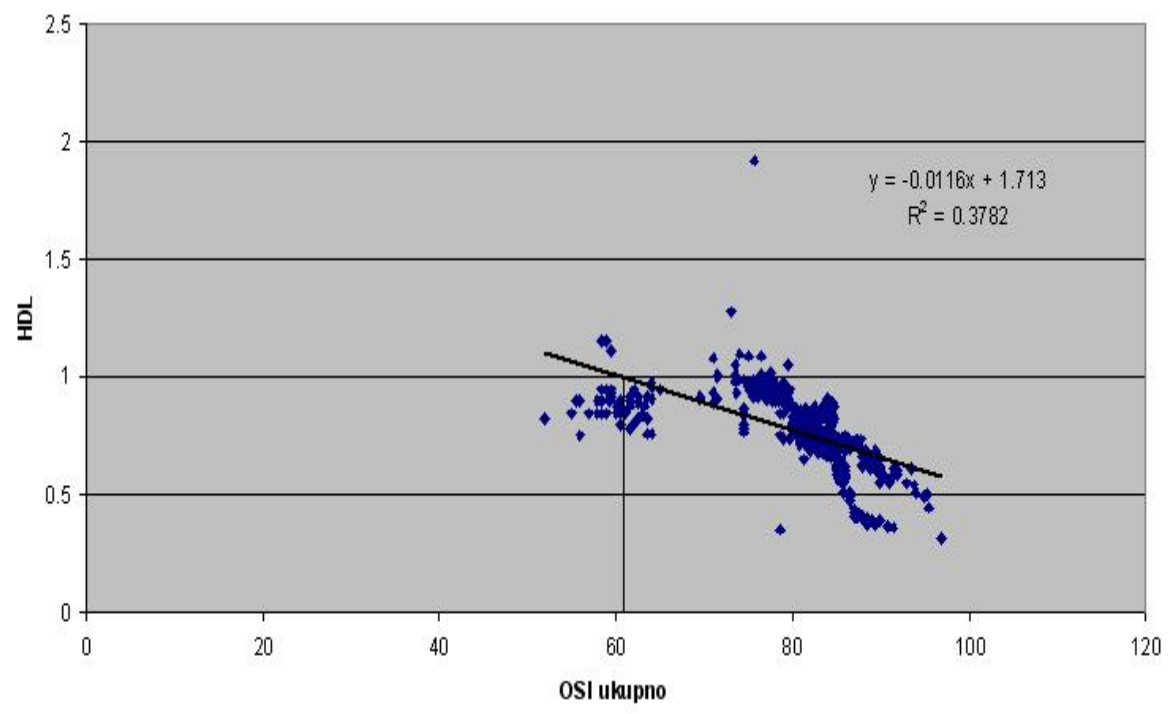

Fig. 2 Correlation analysis of OSI total score (X axis) and HDL cholesterol (mmol/l on Y axis) in the examined group. 
The correlation between OSI and LDL cholesterol in the examined group is positive and statistically significant. The index of professional stress over 75 leads to a significant increase in the level of LDL cholesterol in the examined group (Graphic 3).

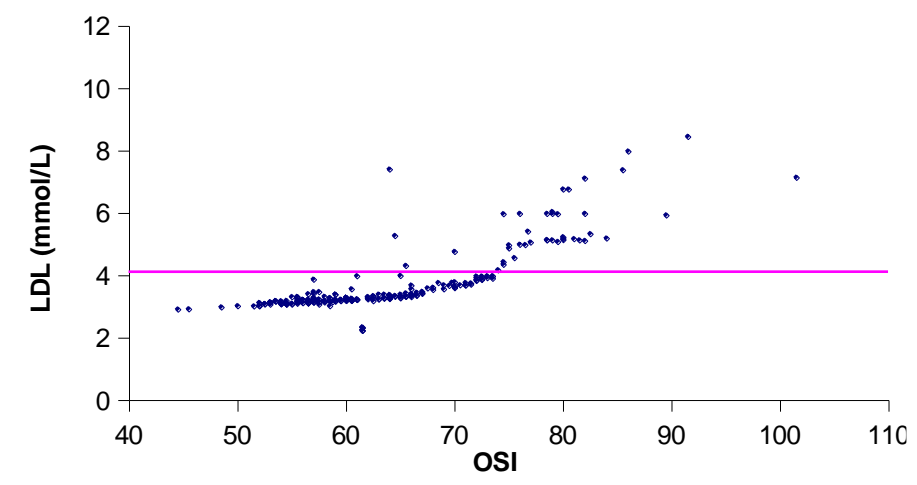

Fig. 3 Correlation analysis of OSI total score and LDL cholesterol in the examined group.

In the examined group, the correlation of OSI with triglycerides was positive and statistically significant. The level of OSI of 65 and more in the examined group represents the threshold value which leads to a significant increase in the serum trilicide concentration in the examined group (threshold value for triglycerides in the examined group) (Graphic 4).

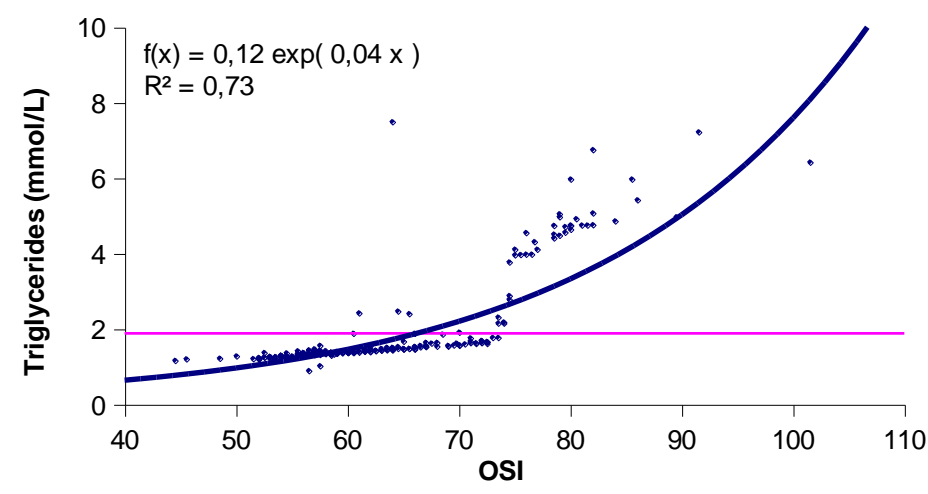

Fig. 4 Correlation analysis of OSI total score and triglycerides in the examined group

\section{DISCUSSION}

Dyslipidemias are on the rise throughout the world [49] and their etiology also occupies a significant place occupational exposure factors, including stress at the workplace $[6,11,12,50]$. In the whole world, but also in our country, there is a dramatic deterioration of morbidity and mortality from cardiovascular diseases, which often result in increased serum lipids [2,15]. Stress at the workplace is in constant expansion [44] and occupies a significant place in the etiology of elevated serum lipid concentrations $[19,34,35]$. This 
study shows a highly significant correlation between the level of overall index of professional stress and increased values of total cholesterol, LDL cholesterol, triglycerides, and decrease in concentrations HDL cholesterol in the serum of officers employed in different types of security. The threshold value of the overall stress level index is particularly high and above that there is a significant increase in serum cholesterol, triglyceride, LDL cholesterol and HDL cholesterol concentrations. It has also been established that the serum lipid parameters depend on the total stress index workplace. These results are in line with our previous studies of the effects of stress on the concentration of lipids in the serum of professional drivers $[20,42]$. Some authors point to the association of metabolic syndrome and work in shifts $[8,13,30]$. Such results are explained by the fact that professional stressors lead to increased secretion of catecholamines, glycocorticoids, and mineralocorticoids. Joint actions of catecholamine and glycocorticoids result in stimulation of $\beta 1$ and $\beta 2$ receptors in the fat tissue resulting in increased lipolysis and vasodilatation in the fat tissue resulting in increased concentration of free fatty acids from which cholesterol and triglycerides are synthesized. Catecholamines inhibit lipoprotein lipase activity [3,31] which, in normal conditions, by the dissolution of low-density triglycerides and low-density lipoproteins, allows the formation of high density lipoprotein (HDL cholesterol). Due to a decrease in the activity of this enzyme, there is an increase in the triglyceride concentration and a decrease in the HDL cholesterol concentration [40]. Such findings have also been confirmed in experimental work on animals that have shown that chronic exposure to steroses results in an increase in blood cholesterol levels, increased accumulation of cholesterol in tissues, and a greater degree of aortic atherosclerosis [36]. There is increasing evidence that some professional stressors are causing an increased production of free radicals that lead to dyslipidemia through increased peroxidation of lipids [21]. The results of this study indicate an increase in LDL cholesterol and a reduction in HDL cholesterol levels under the influence of professional stress, which is a risk factor and can result in acceleration of the process and faster formation of atherosclerosis [23,39,43]. In addition to professional stress, genetic predisposition, the characteristics of the hypothalamus-pituitary-adrenal gland, the lifestyle of the respondents $[18,47,48]$ and the marital status of workers $[14,32]$ have a significant place in the development of these disorders. Some authors have previously investigated and established a link between stress at work and increased levels of blood lipids $[16,17,33]$. Exposure to stress at work, "job strain", leads to an increase in catecholamine secretion, which among other things increases blood coagulability, and through betaadrenergic mechanisms, damage to the endothelium of the blood vessels and clinical manifestations of atherosclerosis [9,24,41] and disturbed nitric oxide production [5] . As a confirmation of the consequence of elevated lipid levels in the serum, the literature provides data, where doppler with an ultrasound examination of carotid arteries determines a significant correlation between high occupational requirements, small rewards and a fouryear progression of carotid atherosclerosis in Finnish workers [29]. The Swedish workers have established a significant correlation between exposure to psychological stress at work with plaque prevalence and thickening on carotid artery bifurcation [37]. Other authors also find the correlation between the degree of psychophysical stress at work and the subsequent occurrence of atherosclerotic changes in the blood vessels [25,26]. The results of this work unequivocally indicate that security officers, due to stress at their workplaces, which leads to increased serum lipid concentrations, are at increased risk for the development of atherosclerosis and its clinical manifestations [7,27], which is why it is necessary to take preventive and protection measures. 


\section{CONCLUSION}

Security officers are exposed to a high level of professional stress, where the level of stress index depends on the type of job they are engaged in. A statistically significant relationship was found between the level of stress in the workplace of security officers and elevated values of total cholesterol, LDL cholesterol, and triglycerides. There is a statistically significant link between elevated levels of the overall index of professional stress in security officers and reduced values of HDL cholesterol. Such results indicate a significant correlation between the type of work, that is, the level of the overall index of professional stress and the pathological values of serum lipids in security officers.

\section{REFERENCES}

1. Apel R. (2013 ). Sanctions, perceptions, and crime: Implications for criminal deterrence. Journal of Quantitative Criminology, 29 (1): 67-101.

2. Assadi SN(2013). Cardiovascular disorders risk factors in different industries of Iran. Int J Prev Med, 4: 728-33.

3. Atsuhito S, Tomokazu O, Kei E, Mariko E, Masahiro O, Nobukiyo K, et all. (2007). Preheparin serum lipoprotein lipase mass might be a biomarker of metabolic syndrome, Diabetes Research and Clinical Practice, 76 (1): 93-101.

4. Belkić K, Savić Č. (2008). The occupational stress index-an approach derived from cognitive ergonomics applicable to clinical practice. SJWEH Suppl; (6): 169-76.

5. Cardilo C, Klcoyne CM, Cannon RO, Panza JA.(1998). Impairment of the nitric oxide mediated vasodilatator response to mental stress in hypertensive, but not in hypercholesterolaemic patients. J Am Coll Cardiol, 32: 1207-13.

6. Catalina-Romero C, Calvo E, Sánchez-Chaparro MA, et al. (2013). The relationship between job stress and dyslipidemia. Scand J Public Health; 41: 142-9.

7. Chaudhary R, Mathew D, Bliden K, Tantry US, Sharma T, Gesheff MG, Franzese CJ, Pandya S, Toth PP, Gurbel PA. (2017). Low-density lipoprotein 4: a novel predictor of coronary artery disease severity. Curr Med Res Opin, 33 (11): 1979-84

8. Cheng Lin Y, Hsiao TJ, Pau-Chung C, Cheng Lin Y, Yuan T.(2009). Shift work aggravates metabolic syndrome development among early-middle-aged males with elevated ALT, World J Gastroenterol., 15(45): 5654-61.

9. Chumaeva N, Hintsanen M, Ravaja N, Juonala M, Raitakari OT, Keltikangas JL.(2009). Chronic Stress and the Development of Early Atherosclerosis: Moderating Effect of Endothelial Dysfunction and Impaired Arterial Elasticity, Int J Environ Res Public Health., 6(12): 2934-49.

10. Dang C, Denis C, Gahide S, Chariot P, Lefèvre T.(2016).Violence at work: forensic medical examination of police officers assaulted while on duty: comparisons with other groups of workers in two centres of the Paris area, 2010-2012. Int Arch Occup Environ Health. 89 (5): 755-65.

11. Djindjic N, Jovanovic J, Djindjic B, et al. (2012). Associations between the occupational stress index and hypertension, type 2 diabetes mellitus, and lipid disorders in middle-aged men and women. Ann Occup Hyg, 56:1051-62.

12. Djindjić N, Jovanović J, Djindjić B, et al. (2013). Work stress related lipid disorders and arterial hypertension in professional drivers - a cross-sectional study. Vojnosanit Pregl, 70: 561-8.

13. Dochi M, Suwazono Y, Sakata K, et al. (2009). Shift work is a risk factor for increased total cholesterol level: a 14-year prospective cohort study in 6886 male workers. Occup Environ Med , 66: 592-7.

14. Empana JP, Jouven X, Lemaitre R, Sotoodehnia N, Rea T, Raghunathan T, Simon G, Siscovick D. (2008). Marital status and risk of out-of-hospital sudden cardiac arrest in the population. Eur J Cardiovasc Prev Rehabil, 15(5): 577-82.

15. Hadjiphilippou S, Ray KK.(2018). Lipids and Lipoproteins in Risk Prediction. Cardiol Clin. 36(2): 213-20.

16. Hammar N, Alfredson L, Johnson JV.(1998). Job strain, social support at work and incidence of myocardial infarction. Occup Environ Med, 55: 548-53.

17. Hammar N, Alfredsson L, Theorel T. (1994). Job characteristics and the incidence of myiocardial infarction. Int J Epidemiol. 23: 277-84. 
18. Hanayo K, Yuko O, Morimoto K.(2009). Long-term effects of lifestyle on multiple risk factors in male workers, Environ Health Prev Med. 14(3): 165-72.

19. Holmes ME, Ekkekakis P, Eisenmann JC.(2010). The physical activity, stress and metabolic syndrome triangle: a guide to unfamiliar territory for the obesity researcher. Obesity Reviews.11, 492-507.

20. Jovanović J, Stefanović V, Stanković DN, Bogdanović D, Kocić B, Jovanović M, Antić Z, Nikolić M, Jovanović J. (2008). Serum lipids and glucose disturbances at professional drivers exposed to occupational stressors. Cent Eur J Public Health, 16(2): 54-8.

21. Julier K, Mackness MI, Dean JD, Durrington PN. (1999). Susceptibility of low and high density lipoproteins from diabetic subjects to in vitro oxidative modification. Diabet Med, 16(5): 415-23.

22. Kajalo S., Lindblom A.(2011). Effectiveness of formal and informal surveillance in reducing crime at grocery stores. Journal of Small Business and Enterprise Development, 18 (1): 157-69.

23. Kawakami N, Akachi K, Shimizu H, Haratani T, Kobayashi F, Ishizaki M, Hayashi T, Fujita O, Aizawa Y, Miyazaki S, Hiro H, Hashimoto S, Araki S. (2000). Job strain, social support in the workplace, and haemoglobin A1c in Japanese men, Occup Environ Med, 57(12): 805-9.

24. Kivimäki M, Nyberg ST, Batty GD, Fransson EI, Heikkilä K, et al.(2012). Job strain as a risk factor for coronary heart disease: a collaborative meta-analysis of individual participant data. Lancet , 380: 1491-7.

25. Krause N, Brand RJ, Kaplan GA, Kauhanen J, Tuomainen T, Salonen JT.(2007). Occupational physical activity, energy expenditure, and 11-year progression of carotid atherosclerosis. Scand J Work Environ Health. 33(6): 405-24.

26. Landsbergis PA, Diez-Roux AV, Fujishiro K, Baron S, Kaufman JD, Meyer JD, Koutsouras G, Shimbo D, Shrager S, Stukovsky KH, Szklo M.(2015). Job Strain, Occupational Category, Systolic Blood Pressure, and Hypertension Prevalence: The Multi-Ethnic Study of Atherosclerosis. J Occup Environ Med, 57 (11): 1178-84.

27. Lee DY, Kim JH, Park SE, Park CY, Oh KW, Park SW, Rhee EJ, Lee WY.(2017). Effects of Low-density Lipoprotein Cholesterol on Coronary Artery Calcification Progression According to High-density Lipoprotein Cholesterol Levels. Arch Med Res, 48 (3): 284-91.

28. Leino TM, Selin R, Summala H, Virtanen M. (2011). Violence and psychological distress among police officers and security guards. Occup Med (Lond), 61(6): 400-6.

29. Lunch J, Krause N, Kaplan GA, Salonen R, Salonen JT. (1997). Work place demands, economic reward, and progression of carotid atheroslcerosis. Circulation, 96: 302-7.

30. Mosendane T, Mosendane T, Raal FJ.(2008). Shift work and its effects on the cardiovascular system. Cardiovasc J Afr, 19: 210-5.

31. Muraba Y, Koga T, Shimomura Y, Ito Y, Hirao Y, Kobayashi J, Kimura T, Nakajima K, Murakami M. (2018). The role of plasma lipoprotein lipase, hepatic lipase and GPIHBP1 in the metabolism of remnant lipoproteins and small dense LDL in patients with coronary artery disease. Clin Chim Acta, 476: 146-53.

32. Panagiotakos DB, Pitsavos C, Kogias Y, Mantas Y, Zombolos S, Antonoulas A, Giannopoulos G, Chrysohoou C, Stefanadis C.(2008). Marital status, depressive episodes, and short-term prognosis of patients with acute coronary syndrome: Greek study of acute coronary syndrome (GREECS). Neuropsychiatr Dis Treat, 4(2): 425-32.

33. Poorabdian S, Mirlohi AH, Habibi E, Shakerian M.(2013). Association between job strain (high demand-low control) and cardiovascular disease risk factors among petrochemical industry workers. Int $\mathbf{J}$ Occup Med Environ Health, 26(4): 555-62.

34. Puustinen PJ, Koponen H, Kautiainen H, Mantyselka P, Vanhala M.(2011). Psychological distress predicts the development of the metabolic syndrome: a prospective population-based study. Psychosomatic Medicine, 73:158-65.

35. Raikkonen K, Matthews KA, Kuller LH.(2007). Depressive symptoms and stressful life events predict metabolic syndrome among middle-aged women: a comparison of World Health Organization, Adult Treatment Panel III, and International Diabetes Foundation definitions. Diabetes Care, 30: 872-7.

36. Ricardo C, María AN, José M. Arbonés M, Sergio A, Mario A., et all.(2007). Folic acid supplementation delays atherosclerotic lesion development in apoE-deficient mice, Life Sciences, 80 (7): 638-43.

37. Rosvall M, Ostergren PO, Hedbland B, Isacsson SO, Jynzon L, Berglund G.(2002). Work related psychosocial factors and carotid atherosclerosis. Int J Epidemiol, 31: 1169-78.

38. Rowland R., Coupe T. (2014) Patrol officers and public reassurance: a comparative evaluation of police officers, PCSOs, ACSOs and private security guards. Policing and Society, 24(3): 265-84.

39. Shao B, Heinecke JW. (2009). HDL, lipid peroxidation, and atherosclerosis, J Lipid Res, 50(4): 599-601.

40. Shirakawa T, Nakajima K, Shimomura Y, Kobayashi J, Stanhope K, Havel P, Machida T, Sumino H, Murakami M. (2015). Comparison of the effect of post-heparin and pre-heparin lipoprotein lipase and hepatic triglyceride lipase on remnant lipoprotein metabolism.Clin Chim Acta, 2, 440: 193-200. 
41. Skantze HB, Kaplan J, Petterson K, Manuck S, Blomqvist N, Kyes R.(1998). Psychosocial stress causes endothelial injury in cynomolgus monkeys via beta1-adrenoceptor activation. Atherosclerosis, 136: 153-61.

42. Stefanović V, Jovanović J, Jovanović M. (2010). The influence of occupational stress on lipid status of road traffic professional vehicle drivers, Med Pregl, LXII (1-2): 57-61.

43. Steinberg D.(2009). The LDL modification hypothesis of atherogenesis: an update, J Lipid Res, 50 (Supplement): S376-S381.

44. Szymanski E.M.(1999). Disability, job stress, the changing nature of careers, and the career resilience portfolio. Rehabilitation Counselling Bulletin, 4: 279-84.

45. Telep C. W., Mitchell R. J., Weisburd D.(2014). How much time should the police spend at crime hot spots? Answers from a police agency directed randomized field trial in Sacramento, California. Justice Quarterly, 31(5): 905-33.

46. Tremblay AJ, Morrissette H, Gagné JM, Bergeron J, Gagné C, Couture P.(2004). Validation of the Friedewald formula for the determination of low-density lipoprotein cholesterol compared with $\beta$ quantification in a large population. Clinical Biochemistry, 37, (9): 785-90.

47. Tsutsumi A., Kayaba K., Kario K., Ishikawa S. (2009). Prospective study on occupational stress and risk of stroke. Arch Intern Med, 169: 56-61.

48. Wirtz P. H., von Kanel R., Emini L., Ruedisueli K., Groessbauer S., Maercker A., Ehlert U. (2007). Evidence for altered hypothalamus-pituitary-adrenal axis functioning in systemic hypertension: blunted cortisol response to awakening and lower negative feedback sensitivity. Psychoneuroendocrinology, 32: $430-6$.

49. World Health Organization,(2013). World Health Statistics. 10-30. Available at: http://www.who.int..

50. Xu W, Hang J, Gao W, et al.(2011) Association between job stress and newly detected combined dyslipidemia among Chinese workers: findings from the SHISO study. J Occup Health, 53: 334-42.

\section{UTICAJ OPTEREĆENJA RAZLIČITIM NIVOIMA PROFESIONALNOG STRESA NA KONCENTRACIJU SERUMSKIH LIPIDA SLUŽBENIKA OBEZBEĐENJA}

Cilj rada je analiza povezanosti nivoa profesionalnog stresa i koncentracija ukupnog holesterola, HDL holesterola, LDL holesterola i triglicerida u serumu službenika angažovanih na različitim vrstama obezbeđenja. Ispitivanjem je obuhvaćeno 415 službenika obezbeđenja (ispitivana grupa) podeljenih u četiri podgrupe $i 150$ administrativnih radnika (kontrolna grupa). Primenom standardizovanog upitnika, je izračunavan nivo profesionalnog stresa na njihovim radnim mestima. Radi određivanja koncentracije lipida u serumu od svih ispitanika je uziman uzorak venske krvi ujutru posle dvanaestočasovne apstinencije od hrane. Službenici obezbeđenja su izloženi visokom nivou profesionalnog stresa, pri čemu nivo indeksa stresa zavisi od vrste poslova na kojima su angažovani. Najviše vrednosti ukupnog indeksa profesionalnog stresa, ukupnog holesterola, LDL holesterola i triglicerida su registrovane kod službenika na obezbedjenju transporta novca sa nošenjem vatrenog oružja. Najniže vrednosti ukupnog indeksa profesionalnog stresa, ukupnog holesterola, LDL holesterola i triglicerida su registrovane kod službenika na obezbedjenju imovine $i$ lica bez nošenja vatrenog oružja. Utvrđena je statistički značajna korelacija između nivoa indeksa stresa na poslu, povećanja vrednosti ukupnog holesterola, LDL holesterola, triglicerida i smanjenja nivoa HDL holesterola. Smatramo da postoji značajna povezanost između nivoa ukupnog indeksa stresa na poslu i rizika od ateroskleroze kod službenika obezbeđenja.

Ključne reči: Služba obezbeđenja, Profesionalni stres, Holesterol, Trigliceridi, LDL holesterol 